Eur. J. Clin. Chem. Clin. Biochem.

Vol. 30, 1992, pp. 285-290

(C) 1992 Walter de Gruyter \& Co. Berlin $\cdot$ New York

\title{
Comparison of Four Procedures for Measuring Elastase Production by Pseudomonas aeruginosa Strains from Cystic Fibrosis Patients ${ }^{1}$ )
}

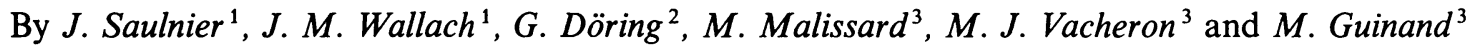 \\ ${ }^{1}$ Laboratoire de Biochimie Analytique, Université Claude Bernard-Lyon I, Villeurbanne, France \\ ${ }^{2}$ Hygiene-Institut, Eberhard Karls Universität, Tübingen, Deutschland \\ ${ }^{3}$ Laboratoire de Biochimie Microbienne, Université Claude Bernard-Lyon I, Villeurbanne, France
}

(Received July 17, 1991/February 2, 1992)

\begin{abstract}
Summary: Forty-five Pseudomonas aeruginosa strains were isolated from the sputa of cystic fibrosis patients. The elastase production of each strain was assayed in the culture supernatant using four different procedures, i.e. two immunological assays (RIA and ELISA), and two enzymatic assays, the latter employing either elastin or tetraalanine as substrate, with conductometric measurement of substrate hydrolysis. Elastase concentrations were determined from standard curves prepared with the same purified elastase, and expressed in $\mathrm{mg}$ of elastase per litre of supernatant. The resulting values were in the range reported in the literature, and differed greatly from one strain to another $(0-230 \mathrm{mg} / \mathrm{l})$. Linear relationships were found when assays were compared in pairs. Significant correlation coefficients were obtained $(r>0.76, p<0.001)$ but the values were quite different for different assays. Thus, ELISA measurements were always from three to five times higher, and RIA results were from two to five times lower, than those from the other assays. Enzymatic assays with elastin gave higher values than those using tetraalanine. Most $P$. aeruginosa strains produce two other proteinases, alkaline proteinase and Las A protein. Both enzymes have limited elastolytic and peptidasic activities. The presence of alkaline proteinase does not result in falsely elevated elastase values, but an increase of elastase activity was observed when Las A was preincubated with elastin. Since this increase was not observed when tetraalanine was used as the substrate, the presence of Las A in the supernatants could explain the differences observed between the enzymatic assays. The assay with the synthetic substrate is therefore preferred.
\end{abstract}

\section{Introduction}

Pseudomonas aeruginosa is an opportunistic pathogen responsible for often fatal infections in patients with a variety of underlying diseases. Several secondary metabolites and extracellular protein toxins are related to its virulence (1). Among them, elastase, one of the extracellulary secreted proteinases plays a dom-

\footnotetext{
1) Funding organisations:

Etablissement Public Régional "Rhône-Alpes"

Association Française de Lutte contre la Mucoviscidose (AFLM)

Lyonnaise de Banque

2) Enzyme:

Pseudomonas aeruginosa elastase, EC 3.4.24.-
}

inant role (2). This endopeptidase, which has been identified and characterized by Morihara and coworkers $(3-5)$, has a broad substrate specificity and, in addition to elastin, cleaves various other proteins of biological importance $(6-8)$.

Most strains of $P$. aeruginosa isolated from patients have been shown to produce elastase $\left.{ }^{2}\right)(10-12)$, although the quantity produced may vary greatly from strain to strain (9). Elastase production has been assessed mainly by enzymatic activity measurements. Assays to detect elastolytic activity include the quantification of clearance zones on elastin plates and the quantification of dye-labelled or radio-labelled elastin hydrolysis by culture supernatants of $P$. aeruginosa 
(13-15). Immunological assays have also been developed. Radioimmunoassay (RIA) and enzymelinked immunosorbent assay (ELISA) allow a direct evaluation of the amount of elastase in culture supernatants $(12-13)$. It has been demonstrated that a good correlation exists between the different methods measuring elastase activities of $P$. aeruginosa strains (13).

In the present study, elastase production was quantified in forty-five $P$. aeruginosa strains isolated from cystic fibrosis patients. With a view to selecting the most reliable method, immunological (RIA and ELISA) procedures and enzymatic assays that monitor the hydrolysis of fibrous elastin or tetraalanine hydrolysis with the conductometric method, were compared.

\section{Materials and Methods}

$P$. aeruginosa strains, isolated from the sputa of cystic fibrosis patients were grown on trypticase soy broth as previously described (16).

$P$. aeruginosa elastase (specific activity: $74.2 \mathrm{mPU} / \mathrm{mg}$ protein) and alkaline proteinase (specific activity: $5.01 \mathrm{mPU} / \mathrm{mg}$ protein) were purchased from Nagase Co., Osaka, Japan. Their purities were checked by polyacrylamide gel electrophoresis according to Laemmli (17), and their concentrations were determined spectrophotometrically (5). P. aeruginosa Las A protein was a generous gift from Dr. D. R. Galloway, Department of Microbiology, The Ohio State University, Colombus, OH, USA.

Antiserum against $P$. aeruginosa elastase was produced in rabbits immunized intramusculary and subcutaneously with $75 \mu \mathrm{g}$ of elastase in Freund's complete adjuvant. The rabbits were boosted twice with the same amount of elastase in Freund's incomplete adjuvant. They were bled 65 days after the first injection and the serum was decomplemented $\left(56^{\circ} \mathrm{C}, 30 \mathrm{~min}\right)$, filter-sterilized and stored at $-20^{\circ} \mathrm{C}$. The whole serum was used without further purification for the ELISA assays, while affinity-purified IgG were prepared for the RIA assays. Both antibody solutions were checked for their antigenic specificity by Western-blotting experiments. ${ }^{125}$ I radiolabelled IgG were obtained as previously described (9).

Elastin, extracted from bovine neck ligament and purified by alkaline treatment, was obtained from Elastin Products Co., Pacific, MO, USA. Tetraalanine was from Bachem, Bubendorf, Switzerland; its purity was checked by RP-HPLC. Bovine serum albumin and $o$-phenylene diamine were purchased from Sigma, Saint Louis, MO, USA. A solution was prepared containing $1 \mathrm{~g} / \mathrm{l} o$-phenylene diamine and $0.4 \mathrm{ml} / 130 \% \mathrm{H}_{2} \mathrm{O}_{2}$ in $50 \mathrm{mmol} / \mathrm{l}$ citrate buffer $\mathrm{pH} 4.5$.

All other products (salts and buffers) were of analytical grade.

\section{Conductometry}

The conductometric method was employed for quantifying enzymatic activities of supernatants, using either insoluble elastin or soluble peptide tetraalanine as a substrate. In a typical experiment, $4 \mathrm{ml}$ of substrate $(2 \mathrm{~g} / 1$ elastin or $0.75 \mathrm{mmol} / \mathrm{l}$ tetraalanine), prepared in $5 \mathrm{mmol} / \mathrm{l}$ Tris- $\mathrm{HCl} \mathrm{pH} \mathrm{8.6,} \mathrm{were} \mathrm{injected}$ in a temperature-regulated conductometric cell (type MCCD, Solea-Tacussel, Villeurbanne, France) at $\mathrm{T}=30^{\circ} \mathrm{C}$. The temperature varied less than $0.01^{\circ} \mathrm{C}$ during the experiments. The enzymatic reaction was initiated by addition of $50 \mu$ of culture supernatant. Conductance changes were monitored over 15-20 min with a B-640 Wayne Kerr bridge. Analysis of data were performed as previously described (18). Activities, expressed in experimental units, were converted into elastase concentrations by means of standard curves (19).

\section{Enzyme-linked immunosorbent assay}

The ELISA was developed for quantification of elastase as described by Hoffman (20). Microtitre plates (Micro Elisa Dynatech) were coated with $100 \mu$ l of purified elastase at 0 to 40 $\mu \mathrm{g} / 1$ in $0.05 \mathrm{~mol} / \mathrm{l}$ carbonate buffer, $\mathrm{pH} 9.6$, or various dilutions of culture supernatants in the same buffer. They were incubated for 2 hours at $37^{\circ} \mathrm{C}$ then $16 \mathrm{~h}$ at $4{ }^{\circ} \mathrm{C}$. The plates were washed three times with phosphate-buffered saline, $\mathrm{pH} 7.4$ saturated with $10 \mathrm{~g} / \mathrm{l}$ bovine serum albumin in phosphate-buffered saline, for $1 \mathrm{~h}$ at $37^{\circ} \mathrm{C}$, then washed again with phosphate-buffered saline supplemented with $0.5 \mathrm{~g} / 1$ Tween 20 . Sera diluted $1: 50$ in phosphate-buffered saline containing $0.5 \mathrm{~g} / 1$ Tween 20 and $10 \mathrm{~g} / \mathrm{l}$ bovine serum albumin were added to the coated wells $(100 \mu \mathrm{l})$. After a $2 \mathrm{~h}$ incubation at $37^{\circ} \mathrm{C}$, the wells were washed five times with phosphate-buffered saline supplemented with $0.5 \mathrm{~g} / 1$ Tween 20 and $100 \mu \mathrm{l}$ of a $1: 500$ dilution of goat antirabbit IgG-peroxidase conjugate in phosphate-buffered saline containing $0.5 \mathrm{~g} / \mathrm{l}$ Tween 20 and $10 \mathrm{~g} / \mathrm{l}$ bovine serum albumin were added. The plates were incubated for $2 \mathrm{~h}$ at $37^{\circ} \mathrm{C}$ and washed three times with phosphate-buffered saline supplemented with $0.5 \mathrm{~g} / 1$ Tween 20 . The ELISA was developed with the $o$-phenylene diamine solution $(100 \mu \mathrm{l})$. After $10 \mathrm{~min}$ at $30{ }^{\circ} \mathrm{C}$, the reaction was stopped with $50 \mu \mathrm{l}$ of $100 \mathrm{~g} / \mathrm{l}$ sodium dodecyl sulphate. The absorbance was read at $490 \mathrm{~nm}$ (Dynatech Minireader II, Denkendorf, Germany) and the elastase concentration was deduced from the standard curve given in figure 1.

\section{Radioimmunoassay}

The RIA was performed as described previously (15). Briefly, microtitre plates were covered with purified rabbit antielastase IgG, then incubated for $2 \mathrm{~h}$ at $37^{\circ} \mathrm{C}$, and overnight at $4{ }^{\circ} \mathrm{C}$. They were washed with phosphate-buffered saline three times and saturated with $50 \mathrm{~g} / \mathrm{l}$ bovine serum albumin in phosphate-

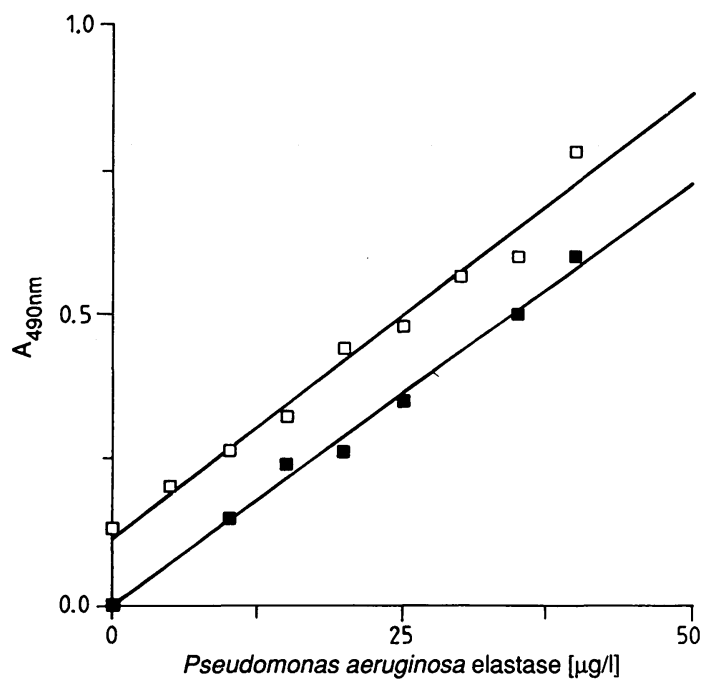

Fig. 1. ELISA standard curves.

Assays were performed as described in Material and Methods. Commercial elastase concentrations were kept between 0 and $40 \mu \mathrm{g} / \mathrm{l}$. Linear relationships were obtained under the following conditions: (- - ) without supernatant, $(-\square-)$ in presence of a $P$. aeruginosa culture supernatant aliquot. 
buffered saline for $4 \mathrm{~h}$ at $37^{\circ} \mathrm{C}$. The plates were then rinsed three times with phosphate-buffered saline, followed by the addition of $100 \mu \mathrm{l}$ of antigen dilutions (purified elastase or culture supernatants) and incubation overnight at $4{ }^{\circ} \mathrm{C}$. The plates were then washed three times with phosphate-buffered saline and saturated with $50 \mathrm{~g} / 1$ bovine serum albumin. One hundred microlitres of rabbit anti-elastase $\left[{ }^{125} \mathrm{I}\right] \mathrm{IgG}$ were added, and the plates were incubated overnight at $4{ }^{\circ} \mathrm{C}$. The wells were washed with phosphate-buffered saline and transferred to a Berthold multicrystal gamma counter (LB 2101). Elastase concentrations were calculated from a calibration curve (9).

\section{Results and Discussion}

Four assays were performed to evaluate elastase production by forty-five $P$. aeruginosa strains isolated from cystic fibrosis patients. Both immunological assays allowed a quantification of the elastase protein. Elastase concentration was also deduced from the enzymatic activities, which were determined with the aid of conductometric procedures. After each assay, the experimental data were compared with corresponding standard curves established with commercial elastase. Each value was the mean of two or three independent assays (SD was less than 10\%).

The results of the assays are listed in table 1. It may be noticed that in all procedures the elastase concentrations varied considerably from one strain to another, but were in the range of the values reported in the literature.

Correlations between the different assays are shown in figure 2. A linear relationship was demonstrated in all cases, with a correlation coefficient (r) always greater than $0.76(\mathrm{p}<0.001)$. The highest correlation coefficient (0.92) was obtained by comparison of the two conductometric assays. When the ELISA results were compared with those calculated from other assays, $\mathrm{r}$ was always higher than 0.80 . On the other hand, the correlation coefficients of RIA data with conductometric data were lower $(r<0.80)$.

Correlation studies never gave a slope value of 1 which would have indicated a total agreement between the results from two different assays. In fact, big discrepancies existed between the slopes. For example, elastase concentrations from the ELISA were 3-4 times higher than concentrations deduced from enzymatic activities. In order to explain the observed differences complementary experiments were carried out: standard curves were constructed with increasing concentrations of purified elastase in the presence or absence of a defined supernatant concentration. Conductometric calibration graphs have already been published (19) whereas the ELISA calibrations are reported in figure 1. For both procedures it was shown that the slope of standard curves obtained in presence of su-
Tab. 1. Elastase concentration of forty-five $P$. aeruginosa strains culture supernatants isolated from cystic fibrosis patients.

Determination was performed by means of four different procedures described in Material and Methods.

\begin{tabular}{|c|c|c|c|c|}
\hline \multirow{3}{*}{$\begin{array}{l}\text { Super- } \\
\text { natant }\end{array}$} & \multicolumn{4}{|c|}{ Elastase concentration $(\mathrm{mg} / \mathrm{l})$} \\
\hline & \multicolumn{2}{|c|}{ Enzymatic assays } & \multirow[t]{2}{*}{ ELISA } & \multirow[t]{2}{*}{ RIA } \\
\hline & $\begin{array}{l}\text { with } \\
\text { elastin }\end{array}$ & $\begin{array}{l}\text { with tetra- } \\
\text { alanine }\end{array}$ & & \\
\hline 1 & 0 & 0 & 0 & 0 \\
\hline 2 & 50 & 58 & 208 & 21.5 \\
\hline 3 & 0 & 0 & 5.5 & 0 \\
\hline 4 & 32.5 & 35.5 & 132 & 29 \\
\hline 5 & 17 & 25.5 & 57 & 23 \\
\hline 6 & 69 & 74 & 202 & 16 \\
\hline 7 & 45.5 & 44 & 226 & 29 \\
\hline 8 & 33.5 & 42 & 129 & 21.5 \\
\hline 9 & 17 & 14 & 11 & 13 \\
\hline 10 & 50 & 30 & 183 & 25 \\
\hline 11 & 0 & 2 & 8 & 2 \\
\hline 12 & 55.5 & 44.5 & 215 & 30.5 \\
\hline 13 & 18 & 14 & 85 & 26.5 \\
\hline 14 & 28.5 & 17.5 & 30 & 29 \\
\hline 15 & 58.5 & 38.5 & 287 & 34 \\
\hline 16 & 16.5 & 8 & 45 & 6 \\
\hline 17 & 54 & 28 & 176 & 33.5 \\
\hline 18 & 40 & 22 & - & 26 \\
\hline 19 & 0 & 0 & 3.5 & 0 \\
\hline 20 & 0 & 0 & 3.5 & 0 \\
\hline 21 & 59.5 & 55 & 123 & 23 \\
\hline 22 & 16 & 0 & 0.5 & 0 \\
\hline 23 & 0 & 0.5 & 7.5 & 2 \\
\hline 24 & 22.5 & 14.5 & 51 & 7 \\
\hline 25 & 32.5 & 19.5 & 79 & 5.5 \\
\hline 26 & 0 & 0 & 8 & 2.5 \\
\hline 27 & 0 & 0 & 7 & 1 \\
\hline 28 & 13 & 9 & 54 & 25.5 \\
\hline 29 & 0 & 0 & 1.5 & 1 \\
\hline 30 & 52 & 45.5 & 255 & - \\
\hline 31 & 0 & 0 & 8.5 & 0 \\
\hline 32 & 42 & 24.5 & 34.5 & 11.5 \\
\hline 33 & 0 & 0 & 17 & 1.5 \\
\hline 34 & 0 & 0 & 3 & 1 \\
\hline 35 & 2.5 & 2 & 14 & 1.5 \\
\hline 36 & 12.5 & 1 & 8 & 2 \\
\hline 37 & 0 & 0 & 1.5 & 0.5 \\
\hline 38 & 0 & 0 & 2 & 0.5 \\
\hline 39 & 45 & 43.5 & 42 & 28 \\
\hline 40 & 31 & 33 & 89 & 25 \\
\hline 41 & 28.5 & 39.5 & 71 & 23 \\
\hline 42 & 0 & 0 & 0.5 & 0 \\
\hline 43 & 33 & 40 & 230 & 37.5 \\
\hline 44 & 20.5 & 13 & - & 22.5 \\
\hline 45 & 0 & 0 & 0 & 0 \\
\hline
\end{tabular}

pernatant never differed from the reference by more than $10 \%$. These results indicate that the culture medium has no influence on the elastase assays. Another explanation may be given: the elastase concentrations were underestimated in the activity assays because deactivation and/or partial auto-digestion of the enzyme produced higher titres of antigen than of active enzyme. On the other hand, the RIA values 

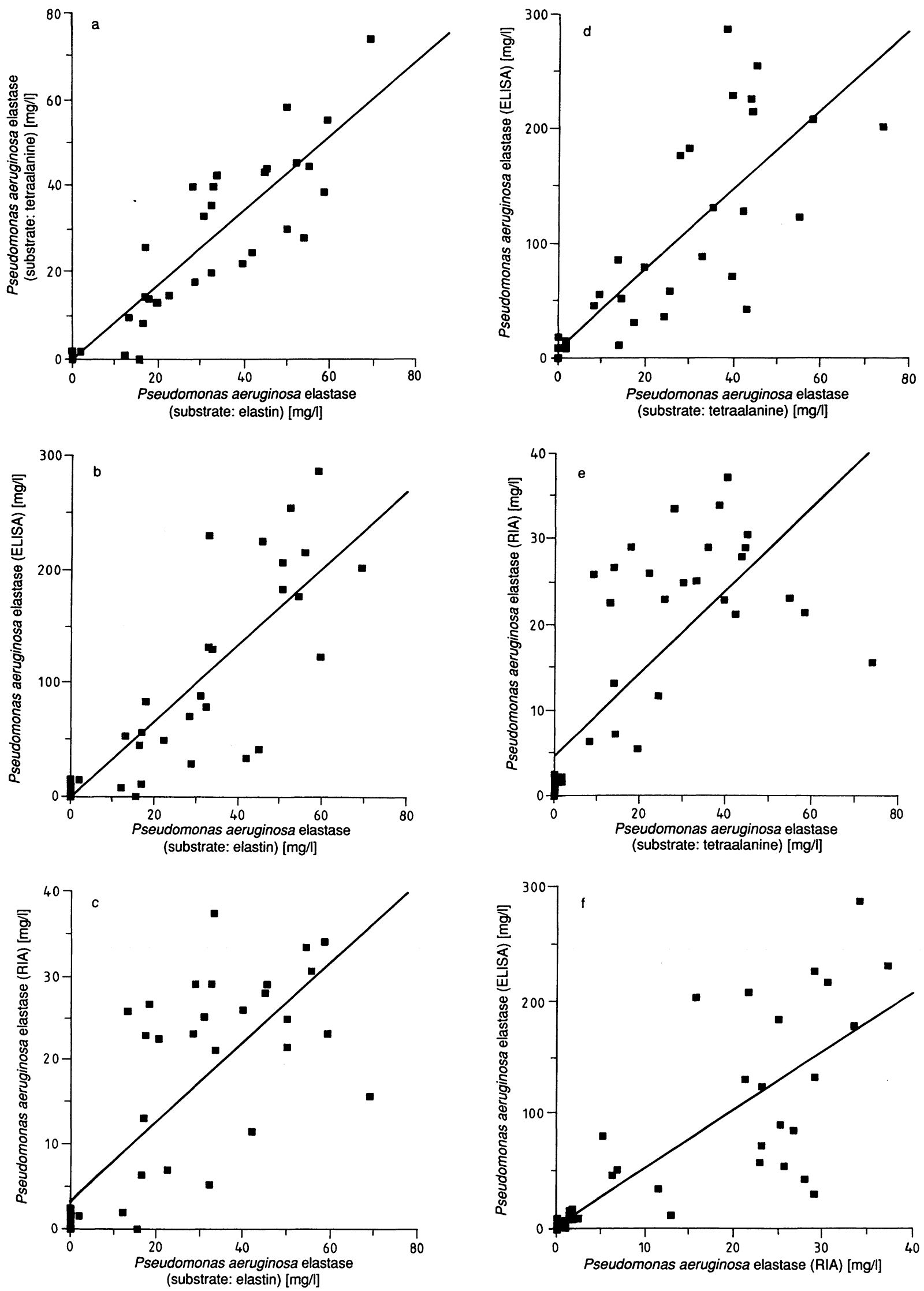

Fig. 2. Comparison of four $P$. aeruginosa elastase assays.

Linear relationships between pairs $(n=45)$ were demonstrated as shown by following equations:
a $\quad \mathrm{y}=0.86 \mathrm{x}-0.47 \quad \mathrm{r}=0.92$
b $\quad \mathrm{y}=3.38 \mathrm{x}-1.10 \quad \mathrm{r}=0.82$
c $y=0.47 x+3.21 \quad \mathrm{r}=0.79$
$\begin{array}{lll}\mathrm{d} & \mathrm{y}=3.49 \mathrm{x}+7.23 & \mathrm{r}=0.84 \\ \mathrm{e} & \mathrm{y}=0.49 \mathrm{x}+4.59 & \mathrm{r}=0.76 \\ \mathrm{f} & \mathrm{y}=5.12 \mathrm{x}+2.12 & \mathrm{r}=0.80\end{array}$

Eur. J. Clin. Chem. Clin. Biochem. / Vol. 30, 1992 / No. 5 
were respectively two and five times lower than the conductometric and ELISA values. Differences in immunological assays may be explained by the use of different antibody preparations, i. e. whole serum for the ELISA and an IgG fraction for the RIA. The slope value obtained by comparison of the two conductometric measurements was found to be equal to 0.86 , indicating a satisfactory agreement between the enzymatic assays. Nevertheless, activities monitored with elastin as the substrate were mostly higher than those measured with tetraalanine.

For a better understanding of the difference between the two conductometric results, complementary experiments were performed. Recently, Peters \& Galloway (21) reported that another proteinase was produced by $P$. aeruginosa, the Las A protein. They demonstrated that this enzyme is able to potentiate the activity of the elastase. This assertion was supported by experiments measuring elastin-Congo red hydrolysis after a $2 \mathrm{~h}$ enzyme-substrate incubation. With a purified sample of Las A, we have recently performed preliminary experiments under initial-rate conditions, with either tetraalanine or insoluble elastin as the substrate. These measurements showed that the Las A protein attacks elastin very slowly compared with elastase, and it shows no activity towards tetraalanine. But when both enzymes were added simultaneously to an elastin suspension, the elastase activity was enhanced about two-fold, the elastase/ Las A ratio being about 2. This phenomena was not observed when the synthetic substrate was used. If, as supposed, Las A was present in the supernatants of bacterial cultures, these observations may explain why measurements with elastin were overestimated. In addition, the capacity of $P$. aeruginosa alkaline proteinase to interfere in the conductometric assays seemed to be negligible, because 1. this enzyme cannot cleave elastin (3), and 2. its activity on tetraalanine is about 25 times lower than that of elastase. Furthermore, we demonstrated that it has no amplifying effect on the elastolytic activity of elastase under initial-rate conditions (the first thirty minutes of reaction).

\section{References}

1. Nicas, T. I. \& Iglewski, B. H. (1985) The contribution of exoproducts to virulence of Pseudomonas aeruginosa. Can. J. Microbiol. 31, 387-392.

2. Wretlind, B. \& Pavlovskis, O. R. (1983) Pseudomonas aeruginosa elastase and its role in Pseudomonas infections. Rev. Infect. Dis. 5, S998-S1004.

3. Morihara, K. (1964) Production of elastase and proteinase by Pseudomonas aeruginosa. J. Bacteriol. 88, 745-757.

4. Morihara, K. (1963) Pseudomonas aeruginosa proteinase I. Purification and general properties. Biochim. Biophys. Acta 73, 113-124.

\section{Conclusion}

In this study four different assays were compared to determine elastase production by $P$. aeruginosa strains isolated from cystic fibrosis patients. Immunological methods gave an estimate of the total elastase present in the supernatant, irrespective of whether the enzyme was active or inactive (deactivation, auto-hydrolysis). The conductometric procedures, however, measured only the total activity of the sample. The methodologies were therefore complementary.

The replacement of elastin by tetraalanine, an elastase-specific substrate, resulted in only minor changes in the conductometric values of activities, and both procedures correlated quite well. With this soluble synthetic substrate, the assay was easy-to-perform and reproducible values of initial velocities were obtained within thirty minutes. As previous results (15) and present ones indicate that the elastase production varies significantly among strains, this methodology may be important for a rapid quantification of elastase activity. The recent development of commercially available conductometric cells renders the method even easier. Furthermore, the current synthesis of new substrates, which are more specifically and more quickly cleaved by $P$. aeruginosa elastase, favours the proposal of the conductometric method for assaying the enzyme activity in supernatants.

This precise and reliable enzymatic assay would be highly useful if a cystic fibrosis therapeutic approach using $P$. aeruginosa elastase inhibitors were to be developed. The level of the elastase production in cultures would be an indication of the state of infection.

\section{Acknowledgement}

We are grateful to Dr. D. R. Galloway for giving us the Las A protein.

This work was supported by grants from Etablissement Public Régional "Région Rhône-Alpes" (Programme Mucoviscidose) and by funds from Association Française de Lutte contre la Mucoviscidose (AFLM). One of us (J.S.) was supported by a grant from Lyonnaise de Banque.

5. Morihara, K., Tsuzuki, H., Oka, T., Inoue, M. \& Ebata, M. (1965) Pseudomonas aeruginosa elastase. Isolation, crystallization and preliminary characterization. J. Biol. Chem. 240, 3295-3304.

6. Döring, G., Maier, M., Müller, E., Bibi, Z., Tümmler, B. \& Kharazmi, A. (1987) Virulence factors of Pseudomonas aeruginosa. Antibiot. Chemother. 39, 136-148.

7. Theander, T. G., Kharazmi, A., Pedersen, B. K., Christensen, L. D., Tvede, N., Poulsen, L. K., Odum, N., Svenson, M. \& Bendtzen, K. (1988) Inhibition of human lymphocyte proliferation and cleavage of interleukin-2 by Pseudomonas aeruginosa proteases. Infect. Immun. 56, 1673-1677. 
8. Horvat, R. T., Clabaugh, M., Duval-Jobe, C. \& Parmely, M. J. (1989) Inactivation of human gamma interferon by Pseudomonas aeruginosa proteases: elastase augments the effects of alkaline protease despite the presence of $\alpha-2$ macroglobulin. Infect. Immun. 57, 1668-1674.

9. Obernesser, H. J. \& Döring, G. (1982) Extracellular toxins of Pseudomonas aeruginosa. IV. Radioimmunoassay for detection of elastase. Zbl. Bakt. Hyg., I. Abt. Orig. A 252, $248-256$.

10. Nicas, T. I. \& Iglewski, B. H. (1986) Production of elastase and other exoproducts by environmental isolates of Pseudomonas aeruginosa. J. Clin. Microbiol. 23, 967-969.

11. Woods, D. E., Shaffer, M. S., Rabbin, H. R., Campbell, G. D. \& Sokil, P. A. (1986) Phenotypic comparison of Pseudomonas aeruginosa strains isolated from a variety of clinical sites. J. Clin. Microbiol. 24, 260-264.

12. Döring, G., Obernesser, H-J., Botzenhart, K., Flehming, B., Hoiby, N. \& Hofman, A. (1983) Proteases of Pseudomonas aeruginosa in patients with cystic fibrosis. J. Infect. Dis. $147,744-750$.

13. Elsheikh, L. E., Bergman, R., Cryz, S. J. \& Wretlind, B. (1986) A comparison of different methods for determining elastase activity of Pseudomonas aeruginosa strains from mink. Acta Path. Microbiol. Immunol. Scand. Sect. B 94, $135-138$.

14. Bjorn, M. J., Sokol, P. A. \& Iglewski, B. H. (1979) Influence of iron on yields of extracellular products in Pseudomonas aeruginosa cultures. J. Bacteriol. 138, 193-200.
15. Jensen, S. E., Phillippe, L., Teng Tseng, J., Stemke, W. \& Campbell, J. N. (1980) Purification and characterization of exocellular proteases produced by a clinical isolate and a laboratory strain of Pseudomonas aeruginosa. Can. J. Microbiol. 26, 77-86.

16. Döring, G., Obernesser, H-J. \& Botzenhart, K. (1982) Extracellular toxins of Pseudomonas aeruginosa. III. Radioimmunoassay for detection of alkaline protease. Zbl. Bakt. Hyg., I. Abt. Orig. A 252, 239-247.

17. Laemmli, U. K. (1970) Cleavage of structural proteins during the assembly of the head of bacteriophage T4. Nature 227, 680-685.

18. Bakala, H., Wallach, J. \& Hanss, M. (1978) Determination of elastolytic activity using a conductometric method. Biochimie 60, 1205-1207.

19. Saulnier, J. M. \& Wallach, J. M. (1991) A conductometric assay of elastase in the supernatant of cultures of $P$. aeruginosa strains. Anal. Chim. Acta 247, 79-82.

20. Hoffman, D. R. (1973) Estimation of serum immunoglobulin $\mathrm{E}$ by an enzyme-linked immunosorbent assay (ELISA). J. Allergy Clin. Immunol. 51, 303-307.

21. Peters, J. E. \& Galloway, D. R. (1990) Purification and characterization of an active fragment of the Las A protein from Pseudomonas aeruginosa: enhancement of elastase activity. J. Bacteriol. 172, 2236-2240.

Dr. J. Saulnier

Laboratoire de Biochimie Analytique

I. C. B. M. C.

Université Claude Bernard-Lyon I

43 Bd du 11 Novembre 1918

F-69622 Villeurbanne Cedex 